\title{
Pre-service Information Technology Teachers' Self-Efficacy, Self- Esteem and Attitudes towards Teaching: A Four-Year Longitudinal Study
}

\author{
Ozcan Ozgur Dursun \\ Anadolu University, Turkey \\ ORCID: 0000-0002-5866-5748
}

\begin{abstract}
This study investigates the changes in self-efficacy perceptions, professional self-esteem, and attitudes towards the teaching profession of pre-service information technology teachers in accordance with their academic achievement and career choices. A longitudinal research was conducted over a four-year time period with participation of 40 pre-service teachers. The data were collected through three separate scales at five different data collection points (entrance, freshman, sophomore, junior and senior years) corresponding to their initial states and their states at the end of each academic year. Findings indicated an improvement in terms of attitude towards the teaching profession and teaching selfefficacy through the time period. However, change in professional self-esteem did not follow such a clear pattern. While grade point averages (GPA) did not show significant relationships with attitude, self-efficacy or self-esteem in earlier states, as the participants gained experience, significant relationships arose among GPA, attitude and self-efficacy. Career choices of pre-service teachers were examined under three categories: teaching, coding and design. Preference for teaching was relatively high at the initial state and continuously increased over time. As the participants progressed in the program, their preference for coding and design increased as well. The increase in career choices of preservice teachers accords with the courses in the program.
\end{abstract}

Keywords: Teacher training; Information technology education; Self-efficacy; Attitude; Self-esteem; Longitudinal study

\section{Introduction}

Teaching is a profession that needs to adapt to contemporary needs of the society and technological developments. This makes it a fruitful field for research that often aims to equip prospective teachers with better qualifications needed in a developing world. These teacher qualifications are discussed under three competency domains: attitude and values, professional knowledge and professional skills (OYGM, 2017). Since the concepts of self-efficacy, attitude, and self-esteem are closely associated with teaching, they have been frequently investigated in the field. Specifically, the development of teaching self-efficacy, positive attitudes towards teaching and professional self-esteem have been desired outcomes of all teacher training programs. Thus, teacher training efforts aim to train highly qualified teachers who hold these qualifications. Bumen and Ozaydin (2013) emphasize the importance of investigating changes in self-efficacy and attitudes over time. Such investigations may help administrators to modify 
educational policies and professional development activities in accordance with the empirical evidence, which can lead to substantial and positive changes in educational practices.

Teacher qualifications are important for students' academic development as well. The existing literature stresses that teachers play key roles in facilitating the academic development of their students. For instance, Curtis (2017) maintained that a teacher's beliefs and attitudes about teaching have strong influences on students' achievement. Similarly, Karabenick (2004) suggested that attitude towards teaching has significant effects on students' performance. Sustaining and improving such positive outcomes is of importance for quality education. To improve teacher qualifications, therefore, various professional development activities are offered for both pre-service and in-service teachers. The teaching literature provides remarkable studies that focus on the effects of teaching self-efficacy on student achievement (e.g., Caprara, Barbaranelli, Steca, \& Malone, 2006; Eells, 2011; Kim, \& Seo, 2018; Klassen, \& Tze, 2014). In addition to student achievement, the presence or lack of teaching self-efficacy has further outcomes. For instance, teachers of low self-efficacy are reported to experience higher levels of work-related stress and have more problems in stimulating instructional activities (Betoret, 2006; Klassen \& Chiu, 2010). Moreover, self-efficacy affects teachers' satisfaction with their jobs (Skaalvik \& Skaalvik, 2007).

Teachers' positive or negative attitudes towards teaching and their perceptions about the prestige of the profession collectively affect their teaching performance. Individuals' attitudes towards their profession determine how they progress in their careers and how they practice in the field (Kiralp \& Bolkan, 2016). Therefore, a positive attitude towards teaching is likely to improve job satisfaction and aid one's professional development as a teacher. Besides, teachers with high levels of self-esteem tend to feel happier in their classrooms and are more effective in teaching (Reilly, Dhingra, \& Boduszek, 2014). Teachers with a positive attitude towards teaching who also have high levels of self-efficacy, teaching enjoyment, and professional selfesteem can make greater contributions to student achievement. Thus, training teachers who have a positive attitude towards and respect for the profession is as important as providing them with high quality domain knowledge.

Self-efficacy, attitude, and self-esteem are intertwined internal motivators that can influence the effectiveness of one's teaching practice. Negative or positive attitudes towards a profession may influence an individual's perception of self-efficacy in that profession. Positive attitudes can increase the respect felt for a profession, and consequently, motivate teachers to improve their field-related competencies such as self-efficacy. Considering the strong relationships among them, these variables can be regarded among the essentials for successful teaching.

It is very important to train successful teachers and promote the competencies required in the current era. Today, technologically-rich learning environments are developed to provide learners with higher-quality learning experiences. In this regard, the current study investigates the attitude, self-efficacy and self-esteem variables which can be both influenced by psychological factors and which are also linked to technology experiences. Especially, the attitude towards technology is one of the popular topics covered in technology acceptance literature. As the literature suggests, attitude towards technology is closely related to ICT use skills (Mustafina, 2015). In addition, there are studies indicating negative relations between teaching experience and ICT use (Inan \& Lowther, 2010; Karaca, Can, \& Yildirim, 2013; Semerci $\&$ Aydin, 2018). These studies show that as the teachers' experiences increase, their closeness towards technology-based instruction change and self-efficacy increase as well along with an expected decrease in negative attitude towards technology usage. Besides, technology usage is 
related to individual's interest in technology rather than external variables such as experience (Lehtinen, Nieminen, \& Viiri, 2016). Therefore, it is very important that pre-service teachers meet with technology in the pre-service period, so they can develop their self-efficacy, interest in technology and positive attitudes toward technology. Similar to self-efficacy and attitude, selfesteem is a variable that is related to psychological well-being and may affect decisions on the use of technology. Thus, it can be said that all teaching programs should consider contemporary technology integration endeavors.

The participants of the current study were pre-service teachers majoring in Computer Education and Instructional Technology (CEIT) department of a state university in Turkey. Having deep technical roots, CEIT departments are under direct influence of technological developments. In addition to following the developments in instructional technology, a pre-service teacher in CEIT should follow contemporary teaching methods and approaches that are modified through these developments. Therefore, their levels of professional self-efficacy, attitude, and professional self-esteem have the potential to influence the chances that they use technology in instructional practices in the future. Pre-service CEIT teachers, equipped with high degree of self-efficacy and self-esteem in their field, will have significant impact not only for themselves but also for the organizational climate. Teachers' attitudes towards ICT use play a key role in promoting ICT use in schools (Seraji, Ziabari, \& Rokni, 2017). They could be an important encourager for the acceptance and use of technology in their institutions as an active technology consultant. In this regard, Abbit (2011) stated that individuals who improve their knowledge and skills about using technology in instructional activities also develop self-efficacy beliefs about facilitating effective learning through technology. Similarly, Chen (2010) emphasized that self-efficacy beliefs are of importance in technology integration. Considering the technology-driven nature of CEIT, a preservice teacher with a negative attitude towards the field and low professional self-esteem or low self-efficacy beliefs is less likely to utilize technology properly in teaching practices.

The teaching self-efficacy perceptions within the CEIT field are directly related to the ability to use technology in teaching and learning processes. Hence, pre-service teachers' self-efficacy perceptions about using technology has the potential to improve their self-confidence in teaching. This self-confidence, in return, is likely to have positive effects on their attitudes towards the teaching profession and their professional self-esteem. In this context, the focus of the current study was to investigate how teaching self-efficacy, attitude towards teaching, and professional self-esteem changed over time in a technology-centered teacher training program along with the interaction across these variables.

Teaching, coding, and design are inherent divisions of the CEIT field. The core of CEIT program includes courses to address the knowledge and skills required by these divisions. Along with the changes in self-efficacy, self-esteem, and attitude, the current study also investigated the changes in the participants' preferences for teaching, coding, and design career paths over a four-year period to provide insights on how the program of study affected pre-service teachers' career choices.

\section{Theoretical Framework}

\section{Teaching Self-efficacy}

Teaching self-efficacy is acquired mostly through direct observations and experiences embodied in pre-service and in-service training activities. As Bandura (1986) maintained in his social 
cognitive theory, observation and modeling are important means of learning. Even though the concept of self-efficacy refers to an individual's self-perceptions, it also refers to one's selfconfidence to accomplish a task. In this regard, self-efficacy belief and individual's success are interdependent (Ozcan, 2008).

From an educational perspective, self-efficacy can be regarded as one of the main factors of learning motivation (Zimmerman, 2000). However, in teaching contexts, it refers to teachers' judgment of whether they can elicit desired outcomes (e.g., engagement and learning) in students (Tschannen-Moran, \& Woolfolk Hoy, 2001). Ashton and Webb (1986) defined teaching self-efficacy as teachers' believes in their ability to have a positive effect on student learning. Tschannen-Moran and Woolfolk-Hoy (2001) defines self-efficacy as a teacher's belief that he or she can make students learn regardless of the circumstances. Similarly, Christophersen, Elstad, Turmo and Solhaug (2016) introduces self-efficacy in teaching as teachers' beliefs about their abilities to teach. Accordingly, the literature suggests that self-efficacy and learning performance have a significant relationship (Graham \& Weiner, 1996) and that individuals of high self-efficacy are more eager to learn and better at handling problems (Zimmerman, 2000). Self-efficacy is also regarded as a strong determinant of academic performance (Fast et al., 2010; Kundu \& Ghose, 2016). For example, Pajares (2006) reported that about $25 \%$ of the variance associated with students' academic performance can be explained through self-efficacy. Therefore, the increase in self-efficacy of individuals is positively reflected on their success (Cikrikci, 2017).

A high level of teaching self-efficacy enables one to acquire new skills that would improve the quality of classroom practice. Beyond that the concept of self-efficacy refers to a personal belief state (Bandura, 1997; Guskey \& Passaro, 1994), high self-efficacy also triggers self-confidence and courage. In this regard, Bandura (1997) argued that learners' self-efficacy beliefs regarding their ability to accomplish academic tasks could improve learners' emotional state and lower negative emotions such as stress, anxiety, and depression. Thus, an individual's belief in his or her ability is one of the pre-requisites of success.

Self-efficacy is a prominent concept in technology integration in education. In this respect, Kim, Kim, Lee, Spector and DeMeester (2013) stressed that it is impossible for teachers to integrate technology into instructional processes when they show low levels of self-efficacy regarding the use of any given technology. Thus, the link between teaching self-efficacy and successful technology integration should be considered. Self-efficacy perceptions are important catalysts for success, whereas the success achieved without meaningful efforts does not support selfefficacy development (Abbit, 2011).

Some scholars argued that self-efficacy beliefs regarding technology use would influence individuals' confidence in their teaching ability (Abbitt, 2011; Wang, Ertmer, \& Newby, 2004). The ability to use technology in instructional environments, therefore, can be regarded as a key concept to explain teaching self-efficacy. Nonetheless, self-efficacy represents a perception delimited by a specific context and/or situation. In other words, self-efficacy in one domain does not predict self-efficacy in other domains (Zimmerman, 2000). On the other hand, Bandura (1986) suggested that accomplished performances, vicarious experience, verbal persuasion, and physiological state are prominent sources of self-efficacy development. Even though Zimmerman (2000) asserted that self-efficacy domains are not connected to one another, selfefficacy development in any domain could facilitate the transfers across the self-efficacy sources discussed by Bandura (1986). This principle applies to teaching self-efficacy as well. As the 
teaching ability involves experience, verbal expression, and persuasion, it is possible for teaching self-efficacy to be transferred to other domains and situations.

In terms of the teaching profession, the concept of self-efficacy refers to the knowledge, skills, and attitudes that are vital to fulfill the responsibilities of a teacher (Demirtas, Comert, \& Ozer, 2011). As the present study was conducted within the CEIT domain, the probability of the participants' evaluating their teaching self-efficacy in terms of their technology use ability was also considered. Hence, the participants' ability to use technology effectively may influence their teaching self-efficacy beliefs within that domain. Moreover, teachers with high levels of selfefficacy are characterized as open to new ideas and eager to try out new instructional methods (Cousins \& Walker, 2000). Similarly, the technology-rich and dynamic nature of the CEIT department requires its practitioners to be open-minded and innovative. Thus, self-efficacy in this domain should be a strong predictor of the professional development.

\section{Teaching Self-esteem}

Self-esteem is defined as an individual's overall negative or positive attitude towards himself or herself (Rosenberg, 1965; Rosenberg \& Simmons, 1975). Individuals' attitudes towards themselves affect their psychological health. In the literature, the relationship between psychological well-being and self-esteem is reported (Fergusson \& Lynskey, 1996). In addition, a high level of self-esteem is considered to be one of the most important indicators of psychological health (Crocker \& Park, 2004). Another definition involves individuals' beliefs about how well they comply with the values of the society (Harmon-Jones et al., 1997). The increase in self-esteem of the individual, being part of the society, is closely related to the social structure. Considering these definitions, an association can be expected between self-esteem and attitudes. Accordingly, the literature reveals a positive relationship between self-esteem and attitude (Kurtz, Amichai-Hamburger, \& Kantor, 2009). In addition to the effect of selfesteem on psychological health, the concept of self-efficacy is also shown to affect psychological health (Drapeau, Saint-Jacques, Lé pine, Be' gin, \& Bernard (2007). Therefore, a relationship can be established between self-esteem and self-efficacy in this context.

Self-esteem refers to an individual's valuation of the self and that value is subject to change by context. In particular, self-esteem can characterize individuals' attitudes towards themselves as well as their attitude towards their profession. A high-level of professional self-esteem can be defined as positioning one's profession well above other professions, whereas a low-level may mean an overall negative perception with regard to one's profession. Hence, professional selfesteem is a perception rather than a reality (Baumeister, Campbell, Krueger, \& Vohs, 2003). Aforementioned perception may be misleading from time to time. Having an inflated/false selfesteem may negatively affect the performance (Baumeister, Campbell, Krueger, \& Vohs, 2003). Therefore, the nature of the self-esteem important as well.

Professional self-esteem regarding teaching can be regarded as a result of one's attitude towards the profession or it can be regarded as a reason behind that attitude. In other words, there is a reciprocal relationship between these concepts. Furthermore, self-esteem is closely related to carrying on the profession (Rendall, Wesson, Anderson, \& Bould, 2009) and academic achievement (Arshad, Zaidi, \& Mahmood, 2015; Gootee, 2016; Hansford \& Hattie, 1982; Judge \& Bono, 2001; Koruk, 2017; Lew \& Harklau, 2018; Peixoto \& Almeida, 2010). This relationship with the success puts self-esteem across the critical attributes. Similarly, learning performance is reported to improve with self-esteem (Baumeister, Campbell, Krueger, \& Vohs, 2003). A 
relationship between self-esteem and gender is also observed in the literature (Arshad, Zaidi, \& Mahmood, 2015; Miconi, Moscardino, Ronconi, \& Altoe, 2017). Thus, an individual's chance to succeed through valuing a profession and improving oneself in that profession should not be disregarded. Therefore, self-esteem was investigated with regard to the teaching profession.

\section{Teaching Attitude}

Attitude is defined as a brief and introductory evaluation of a physical object or an idea (Vogel $\&$ Wanke, 2016). Such evaluations can be either negative or positive. Consequently, attitude is a person's negative or positive evaluations of an object or idea (Bohner \& Wanke, 2014). Although attitude has multiple dimensions and orientations, this study focused on the attitude towards the teaching profession.

Attitude towards the teaching profession shape the interrelations among the instruction, student, classroom environment, and the topic (Guneyli \& Aslan, 2009). Apart from the essential characteristics of the profession, people's predisposition to teaching and integration with environmental conditions may influence their attitudes towards teaching. For example, positive characteristics attributed to the teaching profession by the society or individuals' feelings about teaching could lead them to adopt more positive attitudes towards the profession. Studies reveal numerous external factors that influence attitude formation. The relationship of attitude with several background variables have been reported in the literature such as classroom management (Cetin, 2016), reasons to choose the teaching profession (Nalcaci \& Sokmen, 2016), preferred learning and teaching theories (Bilgin \& Aykac, 2016), gender (Gokdas, 2008; Hancer, 2017), socio-cultural environment (Bhargava \& Pathy, 2014; Gokdas, 2008), and age (Cinpolat, Alincak, \& Abakay, 2016). Moreover, the literature suggests that attitude affects achievement (Ma \& Kishor, 1997) and the positive changes in teacher attitudes contribute to student learning (Guskey, 2002).

As indicated, attitude is an influential factor in teaching and learning processes, which is subject to external influence. Since there is a direct relationship between attitude towards the teaching profession and the quality of teaching activities, an emphasis should be given to how attitude changes over time, and how the attitude towards the teaching profession is related to other variables. A positive attitude towards the teaching profession enhances a teacher's performance in the classroom (Kiralp \& Bolkan, 2016) and contributes to students' learning motivations (Andronache, Bacos, Bacos, \& Macri, 2014). In this regard, studies in the social-psychology revealed the attitude-action relationship (e.g., Ajzen \& Fishbein, 1980; Ajzen \& Fishbein, 1977; Anderson, 1971; Schuman \& Johnson, 1976). As attitude affects teaching efficacy (Kiralp \& Bolkan, 2016), it is important to investigate what external factors contribute to or interfere with an individual's attitude towards the profession. Teachers' success in the profession is as equally important as the external variables that affect their attitudes towards the profession. Therefore, a relationship can be proposed between self-efficacy and attitude towards the profession (Dupagne \& Krendl, 1992; Kundu \& Ghose, 2016).

In the current study, CEIT pre-service teachers' attitudes towards the teaching profession and the changes occurred in their attitudes were investigated. A longitudinal approach was taken because an individual's attitudes towards a topic or a situation are likely to change over time. Considering environmental influences, for example, a positive attitude may transform into a negative one or vice versa. As they major in a technology-focused department, CEIT pre-service teachers' attitudes towards the profession can be examined within the context of technology 
acceptance and use. For instance, Afshari et al. (2009) reported that teachers tend to show more positive attitudes towards instructional ICT applications when they perceive ICT tools as compatible with their methods, easy to use, and observable positive outcomes. Furthermore, Ifenthaler \& Schweinbenz (2013) posited that performance expectancy and facilitating conditions are determinants of the attitude towards the acceptance of a technology. Similarly, positive attitudes towards a technology-focused field would facilitate the effective integration of technology into instructional environments. Thus, the investigation of the changes in CEIT pre-service teachers' attitudes towards the teaching profession as they gain experience in the field can provide us with valuable insights.

To summarize, close conceptual relationships could be presumed among self-efficacy, attitude, and self-esteem. A longitudinal investigation of the entire teacher training experience of preservice teachers can reveal the changes in these concepts along with the interrelationships across them. The breadth of information acquired and special attention given to the teaching profession can contribute to the literature as well. In this context, the purpose of the current study was to investigate the changes in CEIT pre-service teachers' teaching self-efficacy, professional self-esteem, and attitudes towards teaching over the four-year period of their teacher training. In this regard, following research questions were formulated:

1. How is the nature of the relationships across the teaching self-efficacy, professional selfesteem, and the attitude towards the teaching profession over a four-year period of teacher training?

2. Do one's teaching self-efficacy, professional self-esteem, and the attitude towards the teaching profession change over time?

3. How is the nature of the relationship across academic achievement, teaching selfefficacy, professional self-esteem, and the attitude towards the teaching profession?

4. How do pre-service teachers' career choices change over time?

\section{Methods}

\section{Research Models}

The study was designed as a Panel Study which is a type of longitudinal study. In a panel study, the researcher surveys the same sample at different times during the course of a survey (Fraenkel, Wallen, \& Hyun, 2015). A longitudinal study is an observational research method in which data are gathered from the same subjects repeatedly over a period of time. Thus, they include multiple observations which can be realized before, during, or after an intervention. Besides, the timing and number of the data collection steps are organized according to hypotheses of the study (Cook, Campbell, \& Shadish, 2002). While longitudinal designs allow researchers to establish strong accounts of the changes occur in various characteristics of a participant group, these designs are harder to apply due to inherent risks such as prolonged data collection periods and a high chance of participant mortality.

\section{Participants}

The initial participant group were 52 pre-service teachers (33 males - \%63 \& 19 females - \%37) in the CEIT Department of Anadolu University. Participants were informed at the inception and 
during the data collection events that the research design would require dedication over a long period. No bonus or extra credits were given and the participation was completely voluntary. Since the data were collected from the same group over a four-year period, 12 participants with missing data were excluded due to dropping out $(n=5)$, transferring to another school $(n=3)$, and failure to respond to study measures $(n=4)$. The data collection was completed with 40 preservice teachers (26 males $-\% 65$ \& 14 females -\%35) who participated in all data collection phases. The age of the participants varied between 18 and 23 at the inception. Participants' CEIT preference state also varied. Accordingly, $78 \%$ of the participants chose the CEIT department as one of their top five preferences, while $22 \%$ preferred CEIT program as their 6th or later choice.

\section{Data Collection Instruments}

Three different instruments were used. The first one was Ustuner's (2006) single-factor "Attitude towards the Teaching Profession Scale" with 34 items (Cronbach's Alpha=0.93). The second one was Aricak's (1999) single-factor "Occupational Self-Esteem Scale" which sheltered 14 negative and 16 positive statements on occupational self-esteem (Cronbach's Alpha=0.93). The third one was Capa, Cakiroglu, and Sarikaya's (2005) adaptation of the Tschannen-Moran and Woolfolk Hoy's (2001) "Teachers' Sense of Efficacy Scale" with 24 items under three factors (i.e., student engagement Cronbach alpha 0.82, instructional strategies Cronbach alpha 0.86, and classroom management Cronbach alpha 0.84) (Cronbach's Alpha=0.93). Scale scores ranged from 24 to 216. Cronbach's Alpha values for each phase of the study are provided in Table 1.

Table 1. Cronbach's Alpha Reliability for Each Phase

\begin{tabular}{llllll}
\hline & Entrance & Freshman & Sophomore & Junior & Senior \\
\hline Attitude's Scale & 0.76 & 0.90 & 0.81 & 0.83 & 0.83 \\
Self-esteem Scale & 0.87 & 0.91 & 0.94 & 0.95 & 0.96 \\
Self-efficacy Scale & 0.96 & 0.96 & 0.96 & 0.97 & 0.98 \\
\hline
\end{tabular}

Table 1 shows 15 reliability values gathered from five measurements obtained by three separate measurement tools. According to the results, Cronbach's alpha values range from acceptable to high, which suggests that the data collection tools used in the study show reliable results in each measurement.

\section{Data Collection}

The data collection began in the 2013 Fall Semester. "The entrance data" were collected right after the participants were matriculated. That is, they had no previous training so that their initial levels of attitude, self-esteem, and self-efficacy could be observed. At the end of the first academic year (i.e., after completing 12 courses), the same instruments were administered again to obtain "the Freshman data". For the following years, the data collection instruments were administered once again at the end of each Spring semester. The data collected in the spring semesters of 2014, 2015, 2016 and 2017 were named as freshman, sophomore, junior, and senior data respectively. The senior data constituted the fifth and final data collection point. In sum, the data were collected from the same participants using the same instruments five times over four years. 


\section{Data Analysis}

Descriptive statistics pertaining to each measure were calculated and provided first. In order to proceed with parametric tests, univariate and multivariate normality assumptions were met. Most skewness and kurtosis values were between -1 and +1 , which were accepted excellent for a normal distribution (Huck, 2012). Only a few values were between -2 through +2 , which were considered acceptable by George and Mallery (2014). For MANOVA, multivariate outliers were detected and subtracted as well. Besides, relationships across dependent variables were checked to proceed with the MANOVA, which was used to see to what extent the attitude, selfefficacy, and self-esteem means changed over time. Finally, in order to see whether subscales demonstrated a similar pattern across measurement times, a two-way repeated ANOVA was conducted.

\section{Findings}

The mean and standard deviation statistics acquired from attitude, self-esteem, and self-efficacy scales at different time points are provided in Table 2.

Table 2. Descriptive Statistics Pertaining to Each Measure

\begin{tabular}{lllllll}
\hline & Attitude & & Self-esteem & & Self-efficacy & \\
\hline Level & Mean & SD & Mean & SD & Mean & SD \\
\hline Entrance & 2.92 & 0.40 & 3.81 & 0.48 & 6.15 & 1.42 \\
Freshman & 2.98 & 0.50 & 3.73 & 0.51 & 6.34 & 1.23 \\
Sophomore & 3.20 & 0.42 & 3.78 & 0.61 & 6.80 & 1.20 \\
Junior & 3.24 & 0.47 & 3.93 & 0.71 & 6.87 & 1.40 \\
Senior & 3.19 & 0.47 & 3.89 & 0.76 & 7.23 & 1.27 \\
\hline $\mathrm{n}=40$ & & & & &
\end{tabular}

As illustrated in Table 2, there was almost a consistent increase from the entrance measures of the attitude and self-efficacy towards the measurement in the senior year. Such a consistent change was not identified in self-esteem, which began with a higher mean but decreased in the following measurement. These observations need to be confirmed through relevant parametric tests to see whether the changes were statistically significant. In this regard, a MANOVA was conducted. Before the MANOVA, relationships across the dependent variables were examined and summarized in Table 3.

Table 3. Relationships among Measures Across Times

\begin{tabular}{|c|c|c|c|c|c|c|c|c|c|c|}
\hline Time & \multicolumn{2}{|c|}{ Entrance } & \multicolumn{2}{|c|}{ Freshman } & \multicolumn{2}{|c|}{ Sophomore } & \multicolumn{2}{|c|}{ Junior } & \multicolumn{2}{|c|}{ Senior } \\
\hline & SES & SEF & SES & SEF & SES & SEF & SES & SEF & SES & SEF \\
\hline Attitude & $.33^{*}$ & 0.24 & $.36^{*}$ & $.35^{*}$ & $.64^{* * *}$ & $.60^{* *}$ & $.56^{* * *}$ & $.66^{* * *}$ & $.80^{* * *}$ & $.55^{* * *}$ \\
\hline $\begin{array}{l}\text { Self- } \\
\text { esteem }\end{array}$ & & 0.02 & & $.38^{*}$ & & $.64^{*}$ & & $.50^{* * *}$ & & $.60^{* * *}$ \\
\hline
\end{tabular}

SES: Self-esteem; SEF: Self-efficacy; $n: 40 ;{ }^{*} p<.05 ;{ }^{* *} p<.01 ;{ }^{* *} p<.001$ 
Table 3 illustrated that the dependent variables were related with few exceptions. Therefore, a repeated measures MANOVA was conducted to see the changes in dependent variables across the measurement times. The Wilks' Lambda value for the measurement time was statistically significant with a medium effect size (Wilks' Lambda: 0.753; $F(12,407)=3.841 ; p<.001 ;$ partial eta squared $=0.09$ ). This finding revealed that the change in the total dependent variable set was statistically significant. In order to see the source of this change across variables, individual Wilks' Lambda values were examined for each scale. During such an examination, Bonferroni Adjustment was used and the critical p-value was recalculated as 0.0167 (i.e. $0.05 / 3$ ) to cope with the likelihood of committing a Type I Error. Summary statistics are provided in Table 4.

Table 4. Summary of Univariate Tests for Each Scale

\begin{tabular}{llllllll}
\hline Source & SS & df & MS & F & $p$ & $\begin{array}{l}\text { Eta } \\
\text { squared }\end{array}$ \\
\hline Time & Attitude & 3.314 & 4 & 0.829 & 6.320 & 0.000 & 0.139 \\
& Self-esteem & 1.068 & 4 & 0.267 & 1.601 & 0.177 & 0.039 \\
& Self-efficacy & 30.015 & 4 & 7.504 & 7.187 & 0.000 & 0.156 \\
\hline Error & Attitude & 20.451 & 156 & 0.131 & & & \\
& Self-esteem & 26.021 & 156 & 0.167 & & & \\
& Self-efficacy & 162.878 & 156 & 1.044 & & & \\
\hline
\end{tabular}

Univariate tests summarized in Table 4 revealed that the change in means across measurement times was statistically significant for attitude $(p<.001)$ with a medium effect size. Besides, the change was significant for self-efficacy $(p<.001)$ with a large effect size. On the other hand, the change in self-esteem was not significant at all $(p=.177)$. In this regard, pairwise comparisons across measurement times were realized for attitude and self-efficacy through the Sidak Test. Summary of pairwise comparisons is provided in Table 5 and Table 6 successively.

Table 5. Mean differences Across Measures in Terms of Attitude

\begin{tabular}{lcccc}
\hline & Freshman & Sophomore & Junior & Senior \\
\hline Entrance & -0.052 & $-.273^{* *}$ & $-.313^{* *}$ & $-.269^{*}$ \\
Freshman & & -0.221 & -0.260 & -0.217 \\
Sophomore & & & -0.04 & 0.004 \\
Junior & & & 0.043 \\
\hline
\end{tabular}

${ }^{*} p<.05 ;{ }^{* *} p<.01 ; * * *<<.001$

As indicated in the Table 5, attitude scores increased across time. The difference between the entrance level attitudes and further years were obvious. That is, sophomore, junior and senior year means were significantly higher than the entrance means.

Table 6. Mean Differences Across Measures in Terms of Self-Efficacy

\begin{tabular}{lcccc}
\hline & Freshman & Sophomore & Junior & Senior \\
\hline Entrance & -0.188 & $-.649^{* *}$ & $-.724^{* *}$ & $-1.078^{*}$ \\
Freshman & & -0.461 & -0.536 & $-.891^{*}$ \\
Sophomore & & & -0.075 & -0.429 \\
Junior & & & -0.354 \\
\hline
\end{tabular}

${ }^{*} p<.05 ; * * p<.01 ; * * * p<.001$ 
A similar pattern was observed in terms of self-efficacy as well. That is, the difference between the entrance level self-efficacy and the self-efficacy means of further years were obvious. Sophomore, junior and senior year means were significantly higher than the entrance means. In addition, the mean of the senior year was significantly higher than the freshman year.

While attitude and self-esteem were measured through unidimensional scales, self-efficacy had three factors. These factors were student engagement, instructional strategies, and classroom management. In order to see whether these subscales demonstrated the same pattern across measurement times a two-way repeated measures ANOVA test was conducted. Changes in three subscales across five times were examined. Similar to the previous analysis, the main effect for measurement time was significant $\left(F_{4,156}=7.240 ; p<.001\right.$; partial eta squared $\left.=0.157\right)$ whereas the main effect for efficacy subscales $\left(F_{2,78}=0.481 ; p=.620\right)$ and the interaction between efficacy by time was not significant $\left(F_{8,312}=2.055 ; p=.06\right)$. That is, subscale means were similar to each other across measurement times.

Students GPA could be calculated once they completed a semester at the university. As the GPA scores could not be obtained at the entrance data, the relationships among the study variables and the GPA were investigated for the data collected at the end of each school year. For the freshman and sophomore data, GPA did not show a significant relationship with either selfefficacy, attitude or professional self-esteem ( $p>0.05)$. In the junior data, there were significant positive relationships between GPA and attitude $(r=0.32 ; p<0.05)$ and self-esteem $(r=0.403$; $p<0.01)$. Finally, in the senior data, GPA had significant positive relationships with attitude $(r=0.36 ; p<0.05)$, self-esteem ( $r=0.39 ; p<0.05)$, and self-efficacy $(r=0.40 ; p<0.05)$. As the results indicated, GPA's relationships with self-efficacy, attitude, and self-esteem became stronger as the participants gained experience.

Finally, in all data collection points, the participants were asked which career paths they would like to take after graduation from the university. The results regarding the career choices are provided in Table 7.

Table 7. Differences across Measures in Terms of Career Choices

\begin{tabular}{lcclccccccc}
\hline & \multicolumn{2}{c}{ Entrance } & \multicolumn{2}{l}{ Freshman } & \multicolumn{2}{c}{ Sophomore } & \multicolumn{2}{c}{ Junior } & \multicolumn{2}{c}{ Senior } \\
\hline & $\%$ & $f$ & $\%$ & $f$ & $\%$ & $f$ & $\%$ & $f$ & $\%$ & $f$ \\
Teaching & 62,5 & 25 & 63 & 25 & 65 & 26 & 70 & 28 & 80 & 32 \\
Coding & 35 & 14 & 38 & 15 & 53 & 21 & 57,5 & 23 & 57,5 & 23 \\
Designing & 15 & 6 & 20 & 8 & 33 & 13 & 37,5 & 15 & 40 & 16 \\
\hline
\end{tabular}

In addition to computing education courses, information technology teacher training in the CEIT department covers a variety of courses that aim to develop coding and design skills. Therefore, pre-service teachers have many chances to improve themselves in different areas before graduation, and consequently, these learning opportunities are likely to affect their career choices after graduation. As Table 7 indicates, the participants were more inclined to a teaching career at the beginning of their studies. As they took coding and design education in the following years, they continually became more interested in other career paths. Over the course of the study, all three career paths were improved in preference while teaching stayed as the most preferred choice. 


\section{Discussion}

The methodological approach of the current study might allow us to make a unique contribution to the teacher training research. Considering their importance in teachers' professional development, the concepts of teaching self-efficacy, attitude towards the teaching profession, and self-esteem were investigated both individually and collectively to see changes occurred over time. Findings suggested that attitude and self-efficacy improved consistently across the data collection points. While these findings were in line with the findings of Bumen and Ozaydin (2013), they contradicted with Sahin and Atay's (2010) findings in the self-efficacy context. However, the self-esteem scores did not exhibit a consistent improvement pattern. Although there were theoretical relationships among attitude, self-efficacy, and self-esteem, which were also found in the current dataset; the increases observed in attitude and self-efficacy was not available in self-esteem. Hence, the current findings do not comply with the results observed in the literature, which suggest a positive relationship between attitude and self-esteem (Kurtz, Amichai-Hamburger, \& Kantor, 2009). An individual's self-esteem towards his or her profession does not increase parallel with the increasing self-efficacy and attitude, and so, could be investigated further. Considering the findings regarding self-esteem separately, the pre-service teachers had relatively high self-esteem scores regarding the teaching profession at the beginning of the study and the average score remained high throughout the study. This might be due to the respect that students had for the profession prior to the university entrance, which may have led them to choose the teaching degree and increased their readiness. In other words, a significant reason for the participants to choose a teaching career might be the respect they felt for the profession. Similarly, internal and external motivators might influence individuals' decisions to pursue a teaching career (Ekinci, 2017). Further investigations are needed to question such a ceiling effect with regard to initial self-esteem.

The CEIT pre-service teachers' attitudes towards the profession, teaching self-efficacy, and professional self-esteem play facilitating roles in their effective use of technology in instructional processes. Such roles have been investigated through technology acceptance and use models as well. Higher professional self-esteem, improved teaching self-efficacy and more positive attitudes towards the graduation signaled the effectiveness of the current teacher training program offered in the department. Nonetheless, some studies reported a negative relationship between seniority and perceived self-efficacy (Klassen \& Chiu, 2010). Similarly, various studies indicate a negative relationship between the teaching experience and ICT use (Inan \& Lowther, 2010; Karaca, Can, \& Yildirim, 2013; Semerci \& Aydin, 2018). Therefore, it is crucial to identify factors that affect technology use in order to ensure a proper technology integration. Through such an integration, experienced teachers can also be encouraged to make use of technology in teaching and learning activities effectively. For instance, according to the findings of a study by Tugtekin, Barut Tugtekin and Dursun (2018), the experience does not affect the perception of teaching self-efficacy while it is an important predictor of participants' readiness to change. Readiness to change, in this respect, is an intrinsic motivation that has a positive contribution to the issue, as being ready for technology-oriented change would be a catalyzer for the process of technology integration in education. Besides, since rapid developments in technology require us to update the self-efficacy domains frequently in the CEIT field, a similar negative relationship could be observed between seniority and self-efficacy for current CEIT practitioners. Thus, replication of the study with in-service teachers could be quite contributive to the field.

In the study, GPA had significant positive relationships with the attitude towards the teaching profession and self-esteem. Therefore, it is safe to claim that an individual's attitude towards the teaching profession and professional self-esteem improves in response to increasing 
academic achievement. This situation is closely related to achievement motivation. That is, the motivation derived from a sense of success may trigger the development of positive attitudes towards other domains. The literature also reveals a positive relationship between self-esteem and academic achievement (Arshad, Zaidi, \& Mahmood, 2015; Gootee, 2016; Hansford \& Hattie, 1982; Judge \& Bono, 2001; Koruk, 2017; Lew \& Harklau, 2018; Peixoto \& Almeida, 2010) and that an increase in self-esteem may have positive reflections in learning performance (Baumeister, Campbell, Krueger, \& Vohs, 2003; Jackson, 2002). Thus, close relationships across self-esteem, learning performance and academic achievement can be posited.

The CEIT department, in which the study was conducted, aims to train not only information technology teachers but also qualified graphic designers and programmers for the private sector. In this regard, some changes were observed in the career choices of the participants over the years. Those changes were more evident at some specific measurement points that is likely due to the characteristics of the program of study. With the help of the readiness they exhibited at the entrance data, it was observed that the majority of the participants preferred a teaching career. It is expected from students who choose a teacher training institute to have such a readiness and motivation at the beginning of their training. A similar case was observed in the entrance data regarding the attitude variable, in which the participants showed high levels of positive attitudes towards the profession. As the sophomore and junior years involved design and coding courses, career choices on these topics became more prominent. Hence, the differences observed in career choices at different measurement points could be linked to the structure of the program. A comparison between the entrance and the senior data revealed that the preference for a teaching career started high and increased steadily while the preferences for coding and design careers started relatively low yet gained momentum in time. External factors, as well as the curricula, might have an influence on such career choices. For instance, the appointment rates of teachers could be a critical external factor. According to the appointment data pertaining to the time span between 2014 and 2017, which is the period this study took place, an unfavorable picture is observed. That is, while a total of 2014 appointments took place in 2014, it decreased to 420 in 2017 (http://atama.meb.gov.tr). Still, it is confusing that participants' preference for the teaching career has increased contrary to the negative change in the appointment rates. In this regard, it is probable that positive attitude towards teaching profession, self-efficacy and high level of self-esteem motivate individuals intrinsically and even shadow the negative influences of external factors such as decreasing appointment rates. Such speculations should be tested through robust structural equations with further target populations.

\section{Limitations and Recommendations}

The current study investigated how self-efficacy, attitude, and self-esteem changed in the course of a teacher training program. While these variables constituted the scope of the study, socio-psychological and environmental factors that influenced these variables were disregarded. Further studies can provide in-depth investigations of such external factors, particularly the ones that influence attitude and self-esteem. One of the notable findings of the study was that self-esteem scores remained relatively stable while the attitude and self-efficacy scores increased at each measurement point. Given that a positive relationship between attitude and self-esteem was reported quite frequently in the literature, qualitative investigations could be utilized to generate in-depth accounts of why professional self-esteem did not increase in parallel with other variables. Besides, considering the link between selfesteem and psychological well-being, further scholars may consider psychological well-being as 
an additional covariate in further studies. Accordingly, researchers can also focus on the sociopsychological factors influence the teaching practice more directly. Another limitation is the lack of data from in-service teachers. Thus, an additional follow-up study may delve into the data of actual in-service teachers to eliminate the limitation of the current work with regard to involving pre-service teachers only.

The current study employed a longitudinal design. To ensure a sound data collection period, further studies employing this research design can aim to maximize the participation numbers before initiating the data collection process. In order not to lose participants during a relatively prolonged data collection, further studies may implement meaningful incentives to motivate participation.

\section{References}

Abbitt, J.T. (2011). An investigation of the relationship between self-efficacy beliefs about technology integration and technological pedagogical content knowledge (TPACK) among preservice teachers. Journal of Digital Learning in Teacher Education, 27(4), 134143.

Afshari, M., Abu Bakar, K., Luan, W.S., Abu Samah, B., \& Fooi, F.S. (2009). Factors affecting teachers' use of information and communication technology. International Journal of Instruction, 2(1), 77-104.

Ajzen, I. \& Fishbein, M. (1977). Attitude-behavior relations: A theoretical analysis and review of empirical research. Psychological Bulletin, 84(5), 888-918.

Ajzen, I. \& Fishbein, M. (1980). Understanding attitudes and predicting social behavior. Upper Saddle River, NJ: Prentice Hall.

Anderson, N.H. (1971). Integration theory and attitude change. Psychological Review, 78, 171206.

Andronache, D., Bacos, M., Bacos, V., \& Macri, C. (2014). Attitude towards teaching profession. Procedia - Social and Behavioral Sciences, 142, 628-632

Aricak, T. (1999). Self-esteem and vocational self-esteem enhancement through group counseling (Unpublished doctoral dissertation). Marmara University, Istanbul.

Arshad, M., Zaidi, S. H., \& Mahmood, K. (2015). Self-esteem \& academic performance among university students. Journal of Education and Practice, 6, 156-162.

Ashton, P. T. \& Webb, R. B. (1986). Making a difference: Teachers' sense of efficacy and student achievement. New York: Longman.

Bandura, A. (1986). Social foundations of thought and action: A social cognitive theory. Englewood Cliffs, NJ: Prentice Hall.

Bandura, A. (1997). Self-efficacy: The exercise of control. New York: W.H. Freeman and Company.

Baumeister, R.F., Campbell, J.D., Krueger, J.I., \& Vohs, K.D. (2003). Does high self-esteem cause better performance interpersonal success, happiness, or healthier lifestyles?

Psychological Science in the Public Interest, 4, 1-44. 
Betoret, F.D. (2006). Stressors, self-efficacy, coping resources and burnout among secondary school teachers in Spain. Educational Psychology, 26(4), 519-539.

Bhargava, A. \& Pathy, MK. (2014). Attitude of student teachers towards teaching profession. Turkish Online Journal of Distance Education-TOJDE, 15(3), 27-36.

Bilgin, H. \& Aykac, N. (2016). Pre-service teachers' teaching-learning conceptions and their attitudes towards teaching profession. Educational Process: International Journal, 5(2), 139-151.

Bohner, G. \& Wanke, M. (2014). Attitudes and attitude change. New York: Psychology Press.

Bumen, N. \& Ozaydin, E. (2013). Changes on teacher self-efficacy and attitudes towards teaching profession from candidacy to induction. Education and Science, 38(169), 109125.

Caprara, G.V., Barbaranelli, C., Steca, P., \& Malone, P.S. (2006). Teachers' self-efficacy beliefs as determinants of job satisfaction and students' academic achievement: A study at the school level. Journal of School Psychology, 44, 473-490.

Chen, R. (2010). Investigating models for preservice teachers' use of technology to support student-centered learning. Computers \& Education, 55(1), 32-42.

Cinpolat, T., Alincak, F., \& Abakay, U. (2016). Examination of attitudes of physical education and sports college students towards teaching profession. Gaziantep University Journal of Sport Science, 1(1), 38-47.

Cook, T. D., Campbell, D. T., \& Shadish, W. (2002). Experimental and quasi-experimental designs for generalized causal inference. Boston, MA: Houghton Mifflin.

Christophersen, K.A., Elstad, E., Turmo, A., \& Solhaug, T. (2016). Teacher education programmes and their contribution to student teacher efficacy in classroom management and pupil engagement. Scandinavian Journal of Educational Research, $60(2), 240-254$.

Cousins, J.B. \& Walker, C.A. (2000). Predictors of educators' valuing of systemic inquiry in schools. Canadian Journal of Program Evaluation (Special Issue), 25-53.

Curtis, G. (2017). The impact of teacher efficacy and beliefs on writing instruction. Delta Kappa Gamma Bulletin, 84(1), 17-24.

Capa, Y., Cakiroglu, J., \& Sarikaya, H. (2005). The development and validation of a Turkish version of teachers' sense of efficacy scale. Education and Science, 30(137), 74-81.

Cetin, F. (2016). The relationship between the classroom management competence of teachers and their attitudes towards the profession of teaching and job satisfaction. Electronic Turkish Studies, 11(3), 791-808.

Crocker, J. \& Park, L.E. (2004). The costly pursuit of self- esteem. Psychological Bulletin, 130, 392-414.

Cikrikci O. (2017). The effect of self-efficacy on student achievement. In E. Karadag (Ed.), The factors effecting student achievement (pp.95-116). Springer, Cham.

Demirtas, H., Comert, M., \& Ozer, N. (2011). Pre-service teachers' self-efficacy beliefs and attitudes towards profession. Education and Science, 36, 96-111.

Drapeaua, S., Saint-Jacques, M., Le' pinea, R., Be' gin, G., \& Bernard, G. (2007). Processes that contribute to resilience among youth in foster care. Journal of Adolescence, 30, 977-999. 
Dupagne, M. \& Krendl, K.A. (1992). Teachers' attitudes toward computers: A review of the literature. Journal of Research on Computing in Education, 24(3), 420-429.

Eells, R. J. (2011). Meta-analysis of the relationship between collective teacher efficacy and student achievement (Unpublished doctoral dissertation). Loyola University, Chicago, IL, USA.

Ekinci, N. (2017). Pre-service teachers' motivational factors affecting their teaching profession and field choices. Elementary Education Online, 16(2), 394-405.

Fast, L. A., Lewis, J. L., Bryant, M.J., Bacian, K. A., Cardullo, R. A., Rettig, M., \& Hammond, K.A. (2010). Does math self-efficacy mediate the effect of the perceived classroom environment on standardized math test performance? Journal of Educational Psychology, 102(3), 729-740.

Fergusson, D.M. \& Lynskey, M.T. (1996). Adolescent resiliency to family adversity. Journal of Child Psychology and Psychiatry and Allied Disciplines, 37, 281-292.

Fraenkel, J.R., Wallen, N.E., \& Hyun, H.N. (2015). How to design and evaluate research in education (9th Ed.). New York: Mac Graw Hill.

George, D. \& Mallery, P. (2014). IBM SPSS statistics 21 step by step: A simple guide and reference (13th edition). Boston, MA: Allyn \& Bacon/Prentice Hall.

Gootee, M. (2016). Ethnic differences in academic achievement, self-esteem, locus of control, and learning motivation between Filipinos and Caucasians (Unpublished doctoral dissertation). University of the Rockies, Denver, CO.

Gokdas, I. (2008). Bilgisayara yonelik tutumlar. In D. Deryakulu. (Ed.), Bilisim teknolojileri ogretiminde sosyo-psikolojik degiskenler, (pp. 33-54), Ankara: Maya Akademi.

Graham, S. \& Weiner, B. (1996). Theories and principles of motivation. In D.C. Berliner \& R.C. Calfee (Eds.), Handbook of educational psychology (pp. 63-84). New York, NY: Simon \& Schuster Macmillan.

Guskey, T.R. (2002). Professional development and teacher change. Teachers and Teaching, 8(3), 381-391.

Guskey, T.R., \& Passaro, P.D. (1994). Teacher efficacy: A study of construct dimensions. American Educational Research Journal, 31(3), 627-643.

Guneyli, A. \& Aslan, C. (2009). Evaluation of Turkish prospective teachers' attitudes towards teaching profession. Procedia Social and Behavioral Sciences, 1, 313-319.

Hancer, A. (2017). Effects of science teacher candidates' attitudes towards the teaching profession on academic fraud inclinations. Electronic Turkish Studies, 12(6), 387-402.

Hansford, B.C. \& Hattie, J.A. (1982). The relationship between self and achievement/ performance measures. Review of Educational Research, 52, 123-142.

Harmon-Jones, E., Simon, L., Greenberg, J., Pyszczynski, T., Solomon, S., \& McGregor, H. (1997). Terror management and self-esteem: Evidence that self-esteem reduces mortality salience effects. Journal of Personality and Social Psychology, 72, 24-26.

Huck, S.W. (2012). Reading statistics and research (6th ed.). Boston, MA: Pearson.

Ifenthaler, D. \& Schweinbenz, V. (2013). The acceptance of Tablet-PCs in classroom instruction: The teachers' perspectives. Computers in Human Behavior, 29, 525-534. 
Inan, F.A. \& Lowther, D.L. (2010). Factors affecting technology integration in K-12 classrooms: A path model. Education Technology Research and Development, 58(2), 137-154.

Jackson, J.W. (2002). Enhancing self-efficacy and learning performance. The Journal of Experimental Education, 70(3), 243-254.

Judge, T.A. \& Bono, J. E. (2001). Relationship of core self-evaluations traits-self-esteem, generalized self-efficacy, locus of control, and emotional stability-with job satisfaction and job performance: A meta-analysis. Journal of Applied Psychology, 86(1), 80-92.

Karabenick, S. (2004). Perceived achievement goals structure and college student help seeking. Journal of Educational Psychology, 96(3), 569-581.

Karaca, F., Can, G., \& Yildirim, S. (2013). A path model for technology integration into elementary school settings in Turkey. Computers \& Education, 68, 353-365.

Klassen, R.M. \& Chiu, M.M. (2010). Effects on teachers' self-efficacy and job satisfaction: Teacher gender, years of experience and job stress. Journal of Educational Psychology, $102(3), 741-756$

Klassen, R.M. \& Tze, V.M.C. (2014). Teachers' self-efficacy, personality, and teaching effectiveness: A meta-analysis. Educational Research Review, 12, 59-76.

Kim, C.M., Kim, M., Lee, C., Spector, M., \& DeMeester, K. (2013). Teacher beliefs and technology integration. Teaching and Teacher Education, 29, 76-85.

Kim, K.R. \& Seo, E.H. (2018). The relationship between teacher efficacy and students' academic achievement: A meta-analysis. Social Behavior and Personality, 46(4), 529-540.

Kiralp, S.S. \& Bolkan, A. (2016). Relationship between candidate teacher's attitude towards teaching profession and their life satisfaction levels. Anthropologist, 23(1,2), 11-20.

Koruk, S. (2017). The effect of self-esteem on student achievement. In E. Karadag (Ed.), The factors effecting student achievement (pp.274-257). Springer, Cham.

Kundu, A. \& Ghose, A. (2016). The relationship between attitude and self-efficacy in mathematics among higher secondary students. Journal of Humanities and Social Science, 21(4), 25-31.

Kurtz, G., Amichai-Hamburger, Y., \& Kantor, J. (2009). Psychosocial well-being of Israeli students and attitudes toward open and distance learning. International Review of Research in Open and Distance Learning, 10(2).

Lehtinen, A., Nieminen, P., \& Viiri, J. (2016). Preservice teachers' TPACK beliefs and attitudes toward simulations. Contemporary Issues in Technology and Teacher Education, 16(2), 151-171.

Lew, S. \& Harklau, L. (2018). Too much of a good thing? Self-esteem and Latinx immigrant youth academic achievement. Journal of Advanced Academics, 29(3) 171-194.

Ma, X. \& Kishor, N. (1997). Assessing the relationship between attitude towards mathematics and achievement in mathematics: A meta-analysis. Journal for Research in Mathematics Education, 28(1), 26-47.

Miconi, D., Moscardino, U., Ronconi, L., \& Altoe, G. (2017). Perceived parenting, self-esteem, and depressive symptoms in immigrant and non-immigrant adolescents in Italy: A multigroup path analysis. Journal of Child and Family Studies, 26, 345-356. 
Mustafina, A. (2015). The role of teachers' attitudes toward technology integration in school. The Eurasia Proceedings of Educational \& Social Sciences (EPESS), 3, 129-138.

Nalcaci, A. \& Sokmen, Y. (2016). The reasons for pre-service teachers to prefer teaching profession and its relationship with their attitudes toward this profession. Ahi Evran University Journal of Kirsehir Education Faculty, 17(3), 717-727.

OYGM (2017, February, 27). Ogretmenlik meslegi genel yeterlikleri. Ankara: MEB Ogretmen Yetistirme ve Gelistirme Genel Mudurlugu. Retrieved on 10 December 2018 from http://oygm.meb.gov.tr/meb_iys_dosyalar/2017_12/11115355_YYRETMENLYK_MESLEY Y_GENEL_YETERLYKLERY.pdf.

Ozcan, E.A. (2008). Bilgisayar ozyeterlik algisi. In D. Deryakulu. (Ed.), Bilisim teknolojileri ogretiminde sosyo-psikolojik degiskenler, (pp.1-31), Ankara: Maya Akademi.

Pajares, F. (2006). Self-efficacy during childhood and adolescence: Implications for teachers and parents, In F. Pajares \& T. Urdan (Eds.). Adolescence and education, Vol. 5 Selfefficacy beliefs of adolescents, 339-367. Greenwich, CT Information Age.

Peixoto, F. \& Almeida, L.S. (2010). Self-concept, self-esteem and academic achievement: strategies for maintaining self-esteem in students experiencing academic failure. European Journal of Psychology of Education, 25(2), 157-175.

Reilly, E., Dhingra, K., \& Boduszek, D. (2014). Teachers' self-efficacy beliefs, self-esteem, and job stress as determinants of job satisfaction. International Journal of Educational Management, 28(4), 365-378.

Rendall, N.D., Wesson, C., Anderson, L., \& Bould, E. (2009) Students' goal achievement: Exploring individual and situational factors. Electronic Journal of Research in Educational Psychology, 7(3), 1031-1052.

Rosenberg, M. (1965). Society and the adolescent self-image. Princeton, NJ: Princeton University Press.

Rosenberg, F.R. \& Simmons, R.G. (1975). Sex differences in the self-concept in adolescence. Sex Roles, 1(22), 147-159.

Sahin, F.E. \& Atay, D. (2010). Sense of efficacy from student teaching to the induction year. Procedia Social and Behavioral Sciences, 2, 337-341.

Schuman, H. \& Johnson, M.P. (1976). Attitudes and behavior. Annual Review of Sociology, 2, 161-207.

Semerci, A. \& Aydin, M.K. (2018). Examining high school teachers' attitudes towards ICT use in education. International Journal of Progressive Education, 14(2), 93-105.

Seraji, N.E., Ziabari, R.S., \& Rokni, S.J.A. (2017). Teacher's attitudes towards educational technology in English language institutes. International Journal of English Linguistics, $7(2), 176-185$.

Skaalvik, E.M. \& Skaalvik, S. (2007). Dimensions of teacher self-efficacy and relations with strain factors, perceived collective teacher efficacy, and teacher burnout. Journal of Educational Psychology, 99(3), 611-625.

Tschannen-Moran, M. \& Woolfolk-Hoy, A. (2001). Teacher efficacy: Capturing an elusive construct. Teaching and Teacher Education, 17, 783-805. 
Tugtekin, U., Barut Tugtekin, E., \& Dursun, O.O. (2018). Analysis of readiness for change and self-efficacy perceptions of IT teachers and pre-service teachers. Mersin University Journal of the Faculty of Education, 14(3), 1200-1221.

Ustuner, M. (2006). Reliability and validity study of an attitude scale of teaching profession. Educational Administration: Theory and Practice, 45, 109-127.

Wang, L., Ertmer, P.A., \& Newby, T.J. (2004). Increasing preservice teachers' self-efficacy beliefs for technology integration. Journal of Research on Technology in Education, 36(3), 231-252.

Vogel, T., \& Wanke, M. (2016). Attitudes and attitude change ( $2^{\text {nd }}$ ed.). London, New York: Routledge.

Zimmerman, B.J. (2000). Self-efficacy: An essential motive to learn. Contemporary Educational Psychology, 25, 82-91.

Correspondence: Ozcan Ozgur Dursun, Assistant Professor, Department of Computer Education and Instructional Technology, Faculty of Education, Anadolu University, Yunus Emre Campus, Eskisehir, Turkey 